\title{
Critical Literacy and the Communicative Approach: Gaps and Intersections
}

\section{Letramento crítico e abordagem comunicativa: brechas e interseções}

\author{
Kátia Modesto Valério* \\ *Universidade Federal Fluminense (UFF), Niterói, Rio de Janeiro / Brasil \\ katiamv@id.uff.br \\ Andrea Machado de Almeida Mattos** \\ **Universidade Federal de Minas Gerais (UFMG), Belo Horizonte, Minas Gerais / Brasil \\ andreamattosufmg@gmail.com
}

\begin{abstract}
The objective of this paper is to foster reflections on the similarities and differences between the Communicative Approach, one of the best-known methods for teaching English as a Foreign Language (EFL) around the world, and Critical Literacy, a relatively recent trend in the Brazilian EFL scenario, as suggested by the National Guidelines for High School Teaching (BRASIL, 2006). First, we will address the theoretical traditions that give rise to the two teaching approaches, explaining their main concepts. We will then discuss the similarities between the two approaches, as well as their main differences. We claim that the two teaching approaches, however different in their epistemological underpinnings, are not incompatible, but rather complementary. Finally, we suggest an example of an integrated activity that aims to reconcile the objectives of the two approaches.
\end{abstract}

KEYWORDS: communicative approach; critical literacy; English as a foreign language.

RESUMO: O objetivo deste trabalho é promover reflexões sobre as semelhanças e diferenças entre a Abordagem Comunicativa, um dos mais conhecidos métodos para o ensino de inglês como língua estrangeira (ILE) no mundo, e o Letramento Crítico, uma tendência relativamente recente no cenário brasileiro de ILE, conforme sugerido pelas Orientações Curriculares para o Ensino Médio (BRASIL, 2006). Primeiramente, abordaremos as tradições teóricas que dão origem às duas abordagens de ensino, explicando seus principais conceitos. Depois, discutiremos as semelhanças entre as duas abordagens, assim como suas principais diferenças. Nossa pretensão é mostrar que as duas abordagens, embora diferentes em suas bases epistemológicas, não são incompatíveis, mas complementares. Finalmente, sugerimos um exemplo de uma atividade integrada que visa a conciliar os objetivos das duas abordagens.

PALAVRAS-CHAVE: abordagem comunicativa; letramento crítico; inglês como língua estrangeira. 
Choices that teachers make in classrooms are always, in part, decisions about what students and, hence, the nation should become.

(CERVETTI; PARDALES; DAMICO, 2001)

\section{Introduction}

This paper ${ }^{1}$ seeks to point out pathways, raise possibilities, and foster discussions about the teaching of English as a foreign/additional language (EFL/EAL). ${ }^{2}$ Although we take the Brazilian scenario as a starting point, we believe our discussion could be extended to other sociopolitical contexts. Similarly, many of the points we make in relation to English could aid in reflections on the teaching of other foreign/additional languages as well. Inspired by the National Guidelines for High School Teaching (BRASIL, 2006), we intend to highlight the relevance of the teaching of foreign languages for citizenship education, by seeking intersections between Critical Literacy (CL) and the Communicative Approach (CA), and suggesting strategies to fill the gaps between the two pedagogical perspectives.

The communicative approach aimed to revolutionize the teaching of foreign languages. After the implementation of CA, language would no longer be seen as a structure, but as a way of creating meanings. The process of learning a foreign language (FL), therefore, would not mean knowledge of grammatical rules, but the ability to make use of these rules appropriately and efficiently for certain communicative purposes. However, almost 40 years after the implementation of communicative teaching in Brazil

\footnotetext{
${ }^{1}$ A previous version of this paper was published in Portuguese in the Brazilian Journal of Applied Linguistics, in 2010, and was later translated into Spanish and published in the journal Matices en Lenguas Extranjeras, in 2014. This new version has been completely updated and thoroughly revised.

${ }^{2}$ In this paper, we refer to EFL/EAL as interchangeable terms, though we are aware of the subtle differences among the various terms and the implications of using one for the other in different contexts. Other terminologies that may refer to related concepts, which have been widely used in the area of English Language Teaching in non-English speaking countries, are "English as an International Language" (EIL), "World English(es)" (WEs), or "English as a Lingua Franca" (ELF). Jenkins (2006) discusses WEs and ELF, and Jordão (2014) expands this discussion to more recent terms, such as EAL and English as a Global Language (EGL), specifically in Brazilian contexts. For the purposes of this paper, we will be referring mostly to EFL, as this is the context of English teaching in Brazil.
} 
(ALMEIDA FILHO, 2001), grammatical rules - worse than that, in many cases, only grammatical rules - continue to be taught in the vast majority of Brazilian schools. Learning through the authentic and meaningful use of the target language, as suggested by CA, for several reasons, has not yet made its way through the Brazilian educational landscape. Reasons for the non-consolidation of communicative FL teaching, in any of its forms, ${ }^{3}$ in Brazilian schools, include distance between the situation of Brazilian learners and real life communicative situations in the target language; the convenience of the safe ground and lower demands of structural approaches; communicative difficulties in the use of the target language on the part of teachers themselves; the unwillingness of institutions to invest in the implementation of a communicative curriculum; excessively large classes and the conduct which naturally arises from the traditional classroom environment with its fixed arrangement of students sitting in rows and the teacher in center stage; little time for FL classes in the curriculum, and the devaluation of those involved in the educational process, together with the disbelief in the relevance of the discipline. These reasons have been pointed out in official documents for years (BRASIL, 1998, 2006) and brought about in the historical account conducted by Cox and Assis-Peterson (2008), providing evidence that the scenario remains unchanged.

At the same time, internationally, the Communicative Approach has gained new features. The pendulum motion resulting from the decline of its stronger version did not bring communicative teaching to an end. Rather, in its so-called "weak version", it incorporates aspects of formal (phonological, lexical, grammatical, linguistic, and pragmatic) instruction of the target

\footnotetext{
${ }^{3}$ We refer here to the two main versions of the Communicative Approach: the strong version and the weak version. In its "weak" version, the Communicative Approach advocates the importance of creating opportunities for students to use the target language in communicative activities with objectives that can be integrated into a more comprehensive language teaching program, also involving the use of other types of activities. In its "strong" version, the Communicative Approach advocates that one can only acquire the target language through communication. Thus, the goal is no longer to develop activities that promote the use of the target language to activate existing systemic knowledge, but rather becomes the development of the language system itself through communication. According to Richards and Rodgers (2001), the weak version is characterized as an approach that aims at "learning to use" the language, while the goal of the strong version is to "use [the language] to learn it" (p. 155).
} 
language (ELLIS, 2005), which is seen as a breakthrough for an approach whose contributions to the learning of languages remain the focus of much research. Furthermore, the communicative project is reflected in educational policies adopted by countries such as Japan and Taiwan (SAVIGNON, 2001; 2007), as well as Brazil (BRASIL, 2006).

Since the early communicative era, in every implementation of this approach, the central role of the student in the learning process, and his/her needs and interests, is highlighted (SAVIGNON, 2001). To design a national policy for the teaching of a foreign language within the communicative paradigm, it is vital to bear in mind the learners to whom the policy is directed. But how is this possible considering Brazil's vast diversity? Perhaps this immeasurable diversity itself provides an answer, because such heterogeneity can be seen not as a stumbling block, but rather a resource, an invaluable asset for a society that seeks equality and pluralism. Among the needs of the huge range of students at a national level are the capacities to see oneself as able to transform social realities in order to recognize the other as a partner in this transformative process. Acknowledgement of this diversity and the shifts in meanings between contrasting positions in dialog are thus fundamental steps for the emergence of conscious citizens, the ultimate goal of the educational process. Critical Literacy, in this context, constitutes a pedagogical alternative which may kindle a sense of citizenship within the student, contributing to the assertion of his/ her identity, in keeping with other ideas stemming from theories of new literacies and multiliteracies (COPE; KALANTZIS, 2000; LANKSHEAR; KNOBEL, 2003), which are reflected in the National Guidelines for High School Teaching (BRASIL, 2006). Critical Literacy and the Communicative Approach, in this context, seem to hold some of the answers for us to get closer to a viable policy for the teaching of foreign languages. However, how can we reconcile epistemological fields with such distinct traditions, goals, and notions of language and learning? In order to try to answer this question we now examine some of the aspects of the two approaches so that we may draw some parallels between them.

\section{Theoretical traditions}

The Communicative Approach (CA) emerged in the early 1970s (RICHARDS; ROGERS, 2001) in response to a general dissatisfaction 
with more formal approaches, in order to better manage the teaching of foreign languages in the face of the growing needs of a world that was just taking its first steps toward globalization (MCDONOUGH; SHAW, 2003; SAVIGNON, 2001). To make intercultural communication possible, language teaching could no longer be restricted to linguistic competence, which was prioritized by the approaches in vogue at that time. In response, CA emerged, backed by an instrumental view of language $e^{4}$ advocated by philosophers of language, such as Austin (1962) and Searle (1969; 1971), and by the notion of language as meaning potential in Halliday's Functional or Systemic Linguistics (HALLIDAY, 1978). CA was also grounded on the concept of communicative competence proposed by Linguistic Anthropology (DELL HYMES, 1972) in response to the formal cognitive view of Noam Chomsky. ${ }^{5}$

Devoid of the market-driven agenda which boosted the shift to the Communicative Approach in the 1970's, Critical Literacy (CL) is supported by revolutionary values (CERVETTI; PARDALES; DAMICO, 2001; NORTON, 2007). Built upon the assumptions of critical social theory, CL conceives of the text as a product of ideological and sociopolitical forces, and a "site of struggle, negotiation, and change" (NORTON, 2007, p. 6). CL also originates from Paulo Freire's Critical Pedagogy and his view of language as a liberating element. The development of critical consciousness, as set forth by Freire, in response to oppression and economic exploitation of the rural population in Brazil, would enable individuals to "remake their own identities and sociopolitical realities through their own meaningmaking processes and through their actions in the world" (CERVETTI; PARDALES; DAMICO, 2001). Postmodernism has reinforced this inclusive perspective. From this tradition, CL incorporates the notion of discourses or discursive systems as "institutionalized ways of thinking [that] define what can and what cannot be said about a specific topic" (ANDREOTTI, 2006, p. 17), stemming from the intersection of subjects and the sociopolitical context in which they operate and from which they construct meanings.

\footnotetext{
${ }^{4}$ Austin $(1962)$ and Searle $(1969,1971)$ proposed a set of communicative acts which are basically things we do with language. These speech acts originated functional syllabi that would organize the contents to be learned around "knowing how to use language for a range of different purposes and functions" (RICHARDS, 2006, p. 3).

${ }^{5}$ For further information on the origins of CA, see Canale and Swain (1980).
} 
Committed to values, such as justice and the fight against inequality, CL aims to change society, promoting the social inclusion of marginalized groups (ALFORD, 2001) and widening the range of social identities into which people can be transformed (JORDÃO, 2002).

In both approaches, language is seen as a dynamic resource for creating meaning, but CL focuses on the sociohistorical dimension of these meanings. Aiming to develop communicative competence, CA attends to the sociocognitive content of communication. CL, on the other hand, focuses on the ideological role of discourse, and its main objective is the development of critical consciousness (see Table 1). In CL, language assumes a liberating character, as it is from the control and critique of the meanings entrenched in discourses and from the creation of alternative meanings that the conscious citizen is expected to emerge (CERVET'TI; PARDALES; DAMICO, 2001). In other words, CA students learn the foreign language for the interpretation, expression and negotiation of meaning (SAVIGNON, 2001), whereas in CL they learn languages (mother tongue and/or foreign languages) to transform themselves and society if they so desire. For CA, language is an instrument of socialization, whereas for CL it is ultimately an instrument of power and social transformation.

Table 1 summarizes the discussion held in this section:

TABLE 1 - Theoretical traditions, objectives, and notions of language in CA and CL

\begin{tabular}{|l|l|l|}
\cline { 2 - 3 } \multicolumn{1}{l|}{} & \multicolumn{1}{c|}{ Communicative Approach } & \multicolumn{1}{c|}{ Critical Literacy } \\
\hline Origins & $\begin{array}{l}\text { Philosophy of Language } \\
\text { Linguistic Anthropology } \\
\text { Systemic Linguistics }\end{array}$ & $\begin{array}{l}\text { Critical Social Theory } \\
\text { Critical Pedagogy } \\
\text { Poststructuralism }\end{array}$ \\
\hline Objectives & $\begin{array}{l}\text { Development of communicative } \\
\text { competence } \\
\text { (use to learn and learn to use) }\end{array}$ & $\begin{array}{l}\text { Development of critical } \\
\text { consciousness } \\
\text { (learn to transform) }\end{array}$ \\
\hline $\begin{array}{l}\text { Lation of } \\
\text { Implementation }\end{array}$ & $\begin{array}{l}\text { Fostered by activities that involve real } \\
\text { communication. }\end{array}$ & $\begin{array}{l}\text { Fostered by a dialog that elicits } \\
\text { social criticism. }\end{array}$ \\
\hline
\end{tabular}




\section{Concepts and principles}

Although from contrasting theoretical traditions, the two approaches share some of their most basic tenets and concepts. Among these, we will highlight here the role of the learner and the central role of heterogeneity. We will also focus on some principles and concepts that represent contact areas between the two approaches, and therefore serve as excellent ground for pedagogical transposition, such as the notion of genre, authenticity, and multiliteracies, as well as some pedagogical practices disseminated by approaches geared towards the development of linguistic awareness.

\subsection{Learner as protagonist}

CL and CA share a guiding thread - the role of the learner. In the social setting of the classroom, the rules of conduct that grant the teacher a monopoly of knowledge and control over the interactional rules, which include the control of the turn-taking system, gave way to the negotiation of knowledge due to a more flexible vision of the roles enacted in the classroom (WIDDOWSON, 1987). Previously a passive element in the learning process, students started to occupy the limelight in this social scenario, and their active participation in their own learning process was recognized and encouraged.

For CA, this flexibility in roles acts as a facilitator of the learning process, because it allows the learners to take initiative, to exercise intuition and creativity, and to feel more confident to engage in communicative activities in the classroom, which also allows them to take ownership of their learning process. Furthermore, the focus of the classroom activities, which was traditionally on the linguistic code, is redirected towards the learners. This change has led to the consideration of students' cultural backgrounds - their needs, intentions, and expectations are now the point of departure (SAVIGNON, 2001; ALMEIDA FILHO, 2001). That is, for CA, considering the mental frameworks each individual brings to the classroom is a pedagogical necessity that enables the learning process.

For CL, the kind of education promoted by the traditional classroom perpetuates existing power relations, promoting conformity (MONTE MOR; MORGAN, 2014), as it deprives the individual of opportunities for questioning. CL has the opposite goal of traditional education - it seeks to promote the empowerment of the learners, who are encouraged to take 
ownership of their own educational process. Only this kind of involvement can lead them to critical reflection on their culture and daily routine, thus bringing them to question their condition (FREIRE, 1970). Therefore, only a democratic classroom is able to raise the reflections advocated by CL. Starting from the social and historical location of the learners, this humanized environment can help them figure out the discursive systems they face.

The two approaches are, thus, constructivist, as both are aimed at building knowledge from what the learner brings to the learning process. ${ }^{6}$ Therefore, the central role of the learner, in both approaches, requires one to consider the needs of the learner and the diversity of each individual's background. Both the vision of the student in CL as a sociohistorical subject who bears invaluable cultural capital ${ }^{7}$ and the precondition in CA of starting from the learners' previous knowledge in order to turn them into effective communicators necessarily imply the incorporation of the concept of heterogeneity.

\subsection{Heterogeneity}

Both CA and CL in a foreign language, therefore, demand the recognition of the co-existence of cultural diversity, which finds expression in distinct linguistic and cultural systems in linguistic communities, those of the mother tongue as well as those of the foreign language. Just as CA proposes a nonpartisan, distanced gaze in relation to intercultural contrasts, CL claims the same distance with respect to linguistic variation, limiting the importance of the norm to the limited social functions that it can fulfill. By relating the standard forms only to the contexts in which they are used, their superiority can then be demystified and deconstructed, enabling the understanding that, in any culture, different ways of acting do coexist. Therefore, the homogeneous linguistic-cultural system should not be imposed as the only option. This system should be identified, understood and

\footnotetext{
${ }^{6}$ For constructivism, "learning involves an active process in which learners construct meaning by linking new ideas with their existing knowledge" (NAYLOR; KEOGH, 1999, p. 93).

${ }^{7}$ Bourdieu's concept of "cultural capital" refers to "knowledge, skills and other cultural acquisitions, as exemplified by educational or technical qualifications" (BOURDIEU, 1991, p. 14).
} 
mastered as a transforming element, which can be done through observation and analysis of this system compared to other linguistic and sociocultural systems commonly regarded as 'deviations'. Thus, the prestigious linguistic variety, previously seen as the one and only homogeneous system, would now be at the service of citizenship education, which considers the other systems to be instruments of socialization and of expression of individual identity (BRASIL, 2006; CANAGARAJAH, 2013; GARCIA, 2015).

Thus, the contact of the learner with alternative systems from the speech communities of the target language would also be compatible with both approaches. Similarities and contrasts could then be identified not only in relation to the two languages and cultures - the learner's mother tongue and the foreign language - but also in relation to discursive and sociocultural differences that are reflected in both languages. The awareness of this heterogeneity as a means for expression of diversity is consistent with intercultural pragmatics. This area of applied sociolinguistics does not assume that the learner should fit the modus operandi of the target speech community (BOXER, 2002), since it involves a multiplicity of forms. It advocates, rather, that the various lines of conduct be recognized and respected so that interactions among members of different cultures can be successful. Thus, the development of intercultural awareness (CRAWSHAW, 2005) occurs through the acknowledgement of differences, as proposed by CL (BRASIL, 2006), without giving up on values. Quite to the contrary, as the Self is built in opposition to the Other, only the perception of values which are different from ours as intrinsic to one's culture, rather than deviations, can help us have a better notion of the heterogeneity inherent to our own identities.

\subsection{Genre}

As we have seen in the previous section, the selection of texts that depict a single homogeneous system, imposed by a social group, would reinforce the idea that such a system is the only possibility. This would confine other modes of expression to the category of "deviation", which is undesirable for both CL and CA. Therefore, the situational variables that determine the productive conditions of the text, and the text itself must be taken into account. The written text, the usual input in foreign language classes, now shares the limelight not only with oral modes of expression, 
but also with hybrid or multimodal texts (SILVER, 1997), as it is the case of online chat rooms. The channel that is used for communication requires the implementation of different physiological processes and is affected in various ways, among which is the amount of time interlocutors have at their disposal to make themselves understood. Written modes, as a rule, allow for the editing of the text and its subsequent adjustment to the norm, which might make the observation of linguistic diversity problematic.

To have an idea of the myriad modes of expression available to them, learners must have the opportunity to examine texts that involve varying degrees of planning, different levels of formality, as well as different numbers of participants in their construction, since all these dimensions interact to characterize the situations from which texts emerge (CELCE-MURCIA; OLSHTAIN, 2000). From this standpoint, each intersection identified among these dimensions produces different genres, to which the learner can have access. In this respect, the notion of genre becomes excellent ground for the pedagogical transposition of the idea of heterogeneity to the foreign language classroom, and constitutes one more link between CL and CA. Genres emerge from the needs of a discourse community (SWALES, 1990). Therefore, it is in light of the values, expectations, and priorities of this community that texts are produced and interpreted. Given their status as social action, genres lead to the consideration of the sociocultural context in which they originate and which maintains them, foregrounding the social reality that they communicate (BHATIA, 1993). The adoption of the concept of genre can facilitate different levels of textual analysis, as this concept establishes the link among the textual, social, and political dimensions of texts (HAMMOND; DEREWIANKA, 2001; JACOBS; SHEGAR, 2018; JOHNS et al., 2006; PALTRIDGE, 2001).

The adoption of the notion of genre as a parameter allows for bottom up text processing, comprising the study of grammatical, phonological, and lexical patterns in relation to register - a necessary condition for the development of linguistic competence. Genres, based on the formal mental schema of the learners, promote the examination of rhetorical patterns, thereby contributing to their discursive competence. The analysis of the sociocultural context that has produced a particular text also enables the identification of the communicative function that it fulfills, informing the learners and developing their sociolinguistic competence. Thus, this notion seems to fit the objectives of CA perfectly; however, to address the 
challenges proposed by CL, the analysis of a text requires a further step toward the mental schemes brought by the learners so that they can have an even broader view of the text - its ideological character. McLaughlin and DeVoogd (2004, p. 14) argue that "Critical Literacy views readers as active participants in the reading process and invites them to move beyond passively accepting the text's message to question, examine, or dispute the power relations" expressed in the text. These authors agree with Cervetti, Pardales and Damico (2001), when they state that Critical Literacy promotes reflection, transformation, and action. The education of critical citizens, therefore, necessarily involves the identification of the social group whose voices are represented in the texts and, with social change in mind, the consideration of the advantages this group gains from this representation.

Hence, the notion of genre seems to be able to meet the demands of the two approaches (CA and CL), calibrating the heterogeneity proposed by them and serving as a guide not only to curriculum development in various educational contexts (BAX, 2006), but also to the daily practice of education professionals, constituting a powerful ally for the selection and preparation of teaching materials.

\subsection{Authenticity}

Concerns with authenticity naturally arise in the process of selection and preparation of teaching materials. Authentic materials are understood to be "samples of spoken and written language that have not been specifically written for the purposes of teaching language" (NUNAN, 1999, p. 27) and have been described in CA as the most efficient input to prepare the learner for dealing with life situations. Despite the difficulty in gaining permission to use authentic materials (CRAWFORD, 2002), real-life texts, particularly those in the oral mode, seem to be the only ones able to convey certain aspects of genuine interaction (NUNAN, 1999). Although the adaptation often suffered by texts to make them palatable in educational, social, ethical, or even commercial terms may not seem ideal for CA, authenticity is beginning to be perceived as the process of making interaction authentic for its participants, regardless of the materials used (SVALBERG, 2007).

Authenticity for CL is even more pressing, becoming an indispensable ingredient. Adaptations made by the teacher, for example, with the purpose of focusing on a specific grammar point, are the result of abstractions that 
only serve homogeneity and that disfigure the product of social action. The understanding of language as social practice would, thus, be linked to its genesis in a given context, since only this context could facilitate the understanding of the power relations portrayed, maintained, and/or constructed in it. Texts for CL should enable the learner to understand the ideology and sociocultural, discursive and linguistic rules of different social strata in various situations. To illustrate this diversity, consider the different rules of conduct that govern the linguistic behavior of an individual in family, at work, as well as among friends at a gathering, for example. Therefore, how could we accept the use of fabricated data to inform the learner about the discursive practices of different social groups? How could an author create an interaction between classmates in a school game, for example, without imposing his or her own linguistic, cultural, and ideological patterns and his or her own interpretative perspectives?

Although the search for authenticity seems to be a further point of contact between the two approaches considered here, its implementation is not among the advances in teaching foreign languages that can be envisioned. In the present scenario, authenticity surrenders to the market and international copyright laws, as international restrictions on the use of texts and images for pedagogical purposes hold back the advances both CA and CL advocate.

\subsection{Multiliteracies}

As CA has emerged from the need for individuals and institutions to function in a globalized world, communicative resourcefulness in a highly computerized and digitized society (LANKSHEAR; KNOBEL, 2003) is a relevant concern. It is known that computer mediated communication is an instrument for the development of discursive competence with regard to digital genres in the target culture. In its asynchronous forms, such as email and blogs, as well as synchronous, such as chat rooms and conversations, or meetings with voice and video via programs such as Skype and MSN, digital mediation enables the learner to communicate in a meaningful and authentic manner (SOKOLIK, 2001), which is a central strategy for the development of communicative competence. As already pointed out, the digital communication environment is multimodal, i.e. the information is provided not only in the form of written texts, but also through other 
multimodal elements. According to Silver (1997), multimodal elements can include texts, photographs, images and graphs, video and podcasts, and even animations. However, the multimodality and multidimensionality of digital genres make it urgent for the Communicative Approach to account for how meaning-making occurs as a whole (MORIN, 2000), rejecting fragmentation or linearity. Curricular organization based on content, compartmentalized in the development of each of the four macro skills (reading, writing, oral comprehension, and oral production) in isolation is refuted. These give way to the integrated development of the necessary communication skills in a broader sense in activities that are meaningful to the learner.

CL seeks to include the individual in the world. However, to effectively become part of the globalized contemporary society, and act within and upon it, the learner must have access to different forms and dimensions of the language of the current technological age. The citizen-reader, educated through a critical approach, can circulate through visual, digital, multicultural, and critical language daily. Such education is, thus, urgent since the speed and ease of access to information, made possible by technological innovations, increase the gap between literate and illiterate individuals at an astounding pace, the latter seeing themselves more and more distant from the society to which they seek to belong.

Thus, multimodal literacies (COPE; KALANTZIS, 2000) are a vital tool for the aspirations of both approaches, as they make the possibility of integration among members of different speech communities real, establishing new discursive communities that are independent of geopolitical boundaries (SAVIGNON, 2007). The command of multimodality is, therefore, a facilitator of individual mobility and enables a "dialogue of cultures [... where] culture is seen to be a concentration of all other meanings (social, spiritual, logical, emotional, moral, esthetic) of human existence" (BIBLER, 1991, cf. SAVIGNON, 2007, p. 212).

\subsection{Language Awareness}

Introduced in the 1970s so as to establish contact between the teaching of the mother tongue and foreign language education in the school curriculum in the UK (HAWKINS, 1999), language awareness has become a field of study and practice which can establish links between CA and CL.

Since the early 1990s, language awareness has become established in communicative teaching, with various studies on the facilitative role 
that language awareness can play in the learning process (SVALBERG, 2007). In the so-called weak version of the Communicative Approach, the cognitive strand of language awareness has gained ground through debates over a focus on form. Reflection, a common characteristic among the methodologies focused on the development of language awareness, plays a key role in this version, as it fuels the metatalk that mediates the process of appropriation required for foreign language learning (TOCALLI-BELLER; SWAIN, 2005). Moreover, learning theories compatible with CA began to consider individual variables for language acquisition and strategies for dealing with these variables, aiming at optimized autonomous learning. From the 1980s on, this concern has brought reflective practices to the forefront of foreign language teaching as a means to develop learners' knowledge about their own learning process. Directed towards self-knowledge, reflection is viewed as an introspective process, which serves as an indicator of success in the learning process (NUNAN, 1999). By means of reflection, learners are led to seek within themselves the way they relate to the content they are to learn and to the learning process as a whole. Another area of linguistic awareness widely discussed in communicative teaching is the acquisition of pragmatic competence. Discussions about cultural differences, more or less explicitly raised, as part of planned pedagogical actions, can help make learners aware of the sociolinguistic norms of the foreign language and culture, as well as of their own ability to accommodate to them (JUNG, 2001). With respect to intercultural pragmatics, metatalk and the reflection it entails enable the development of linguistic awareness - this time in relation to cultural aspects, such as the variability of expression and interpretation of direct and indirect speech acts, politeness, and the discourse functions of conversational markers, for example.

$\mathrm{CL}$ is concerned with language awareness as far as power relations are concerned (JAMES; GARRET'T, 1991). Critical language awareness also sees language as a dynamic phenomenon. However, the awareness CL searches for is not confined to knowledge, but relates to a socially situated process: awareness in Freirean terms. Unlike other areas of linguistic awareness, which question prescription and promote the description of language use, CL awareness sees the CA notion of adequacy in lieu of correction as merely a way of covering up the reasons to use a particular variety, leaving the sociolinguistic situation conveyed in the discourse unquestioned. Instead, correctness and adequacy are seen as vehicles for the perpetuation 
of an ideology. For critical language awareness, the development of communicative skills should not be subject to economic power, but rather be used to subvert the status quo. In other words, the reflection and metatalk encouraged in CL need to go far beyond the linguistic domain in order to be able to locate the learner in relation to the unsaid - not to what was implied, but to what was silenced: the audience which the text serves and the ideology it disseminates. For Freire ([1970] 2005), the expression of critical reflection is a transforming agent, as it leads to practice:

Within the word we find two dimensions, reflection and action, in such radical interaction that if one is sacrificed - even in part - the other immediately suffers. There is no true word that is not at the same time a praxis. Thus, to speak a true word is to transform the world. (FREIRE, [1970] 2005, p. 87)

All texts, oral, written, or multimodal, to which learners have access, as well as the activities they perform, should then allow not only the perception of heterogeneity within and among cultures, but also the development of a detached, critical look with regard to the contents provided by the text.

We can see, therefore, that both approaches benefit from linguistic awareness, promoting metatalk and reflection. However, they do so in totally divergent ways. The reflection proposed in CA does not address the concerns of CL, and vice versa, because they have different objectives. In $\mathrm{CA}$, reflection addresses the learning process itself, whereas in CL it serves the development of critical consciousness. Both would indicate a diagnosis, but in CA this diagnosis would serve to solve a problem or complete a task. In CL, however, this diagnosis would seek to uncover a problem, allowing greater control of the problematic situation, aimed at action and change. One could say, perhaps, that, in CA, reflection would focus on providing practical solutions; whereas for CL, reflection would be directed to problematizing, enabling the recognition of a state of affairs which would otherwise be perpetuated.

There is an obvious gap between the two approaches, which does not necessarily imply that they are incompatible. Quite to the contrary, with respect to reflection and metatalk, the two approaches seem to be complementary, as long as pedagogical practice bridges their demands. In this case, learners would beled along various levels of reflection - they would turn to themselves in order to take possession of their learning process; they would 
turn to the text in order to master its semantic, lexico-systemic, discursive, and pragmatic contents; and, finally, they would turn to the sociohistorical setting of their interaction with the text in order to take control of their own history and design it in accordance with their aspirations.

\section{Reconciling the two approaches - an example for the EFL classroom}

Communicative activities could incorporate a critical literacy stance if a new phase is added, with one of the previous steps serving as input to the questioning that is essential to social criticism. The metatalk elicited by the activity could serve the development of both communicative competence and critical consciousness - distinct, but complementary purposes. Hence, in theory, the intended alternative transformative discourse would also take place in the foreign language. In practice, however, the production of highly complex meanings in a foreign language would require learning conditions that differ greatly from those of the current Brazilian scenario. Nevertheless, we believe that flexibility, compromise, and creativity are essential strategic elements that would allow the compatibility of the two approaches, as we will see below.

As an example that could reconcile the two approaches, we suggest an integrated activity for the development of oral and written communication, which we believe can serve as inspiration for those teachers who wish to adopt a critical stance, without abandoning the precepts of CA. As the context of use, rather than the grammatical rule, is the starting point for CA, we propose as input the use of two excerpts of the John Madden 2011/2012 film The Best Exotic Marigold Hotel. The film tells the story of British retirees who decide to live in a hotel in India, which had been advertised as recently restored and luxurious. However, their decision evolves in unexpected ways both in relation to the hotel and to life in India as a whole. In this way, the plot provides situations which involve interactions among guests and hotel staff - the aim of the activity suggested below.

The theme of the activity relates to diversity, more specifically, to the attitude and communicative strategies employed in face of problems related to travel. Despite following the usual procedures of a typical communicative classroom (see Table 2), a CL element is added towards the end. Rather than leading to the situational, linguistic, and discursive aspects of the text, to meet the demands of CL, this activity goes a few more steps so as to foster critical thinking. This critical element is introduced by a dialogue challenging 
the normalized representations brought about by the input text. In this case, questions seeking a critical stance, interrogating the access to some amenities of our society (such as hotel accommodation, for example) can be made in the target language and debated in the mother tongue, if necessary. ${ }^{8}$

TABLE 2 - Stages of a foreign language class reconciling CA and CL: listening comprehension activity 9

\begin{tabular}{|c|c|c|c|}
\hline \multicolumn{4}{|c|}{ EXCERPT 1 - HOTEL CHECK IN (01:56:05 - 01:56:25 min) } \\
\hline \multirow[b]{2}{*}{ Pre-Listening } & \multicolumn{2}{|c|}{$\begin{array}{l}\text { Activation of content schemes on the issue of traveling } \\
\text { abroad }\end{array}$} & $\begin{array}{l}\text { General questions about } \\
\text { students' previous knowledge. }\end{array}$ \\
\hline & \multicolumn{2}{|c|}{$\begin{array}{l}\text { Activation of formal and content schemes regarding } \\
\text { "hotel check-in" }\end{array}$} & $\begin{array}{l}\text { Check in } \\
\text { Make a reservation } \\
\text { Book a room } \\
\text { Booked up } \\
\text { Hotel receptionist/ manager }\end{array}$ \\
\hline \multirow{4}{*}{ Listening } & $\begin{array}{l}\text { Contexts of use (questions to } \\
\text { check the comprehension of the } \\
\text { situation presented in the oral text) }\end{array}$ & \multicolumn{2}{|c|}{$\begin{array}{l}\text { What is the situation? } \\
\text { Who are the participants? } \\
\text { What is the purpose of the tourists? } \\
\text { What are the problems that they face? }\end{array}$} \\
\hline & Communicative skills & \multicolumn{2}{|c|}{$\begin{array}{l}\text { Identification of communicative functions (ask for } \\
\text { and provide information; request, give and confirm } \\
\text { information). }\end{array}$} \\
\hline & Linguistic aspects & Interrogative Forms & $\begin{array}{l}\text { Do you have a ...? } \\
\text { What's the ...? } \\
\text { Are you sure it's...? }\end{array}$ \\
\hline & & Adverbial Phrases & actually; definitely \\
\hline
\end{tabular}

\footnotetext{
${ }^{8}$ We understand that the inclusion of this critical element is too important to be left out. Therefore, if the discussion cannot be carried out in the target language due to the lack of FL communicative skills, it should still take place in the mother tongue.

${ }^{9}$ This activity was designed based on the suggestion from the National Guidelines for High School Teaching for a "Dialogue between a hotel receptionist and foreign guest about local customs" (BRASIL, 2006, p. 121). In this activity, the critical element is introduced at the end. However, it need not always be like that. Depending on the focus of the activity, CL may be used at any stage to foster critical thinking.
} 


\begin{tabular}{|c|c|c|c|}
\hline \multicolumn{4}{|c|}{ EXCERPT 2 - COMPLAINING IN A HOTEL (00:23:32 min) } \\
\hline \multirow{2}{*}{ Pre-Listening } & $\begin{array}{l}\text { Activation of content } \\
\text { schemes on the issue of making } \\
\text { complaints }\end{array}$ & \multicolumn{2}{|c|}{ General questions about students' previous knowledge } \\
\hline & $\begin{array}{l}\text { Activation of formal and } \\
\text { content schemes regarding } \\
\text { complaining }\end{array}$ & \multicolumn{2}{|l|}{$\begin{array}{l}\text { I'd like a refund } \\
\text { I'm sorry, but... }\end{array}$} \\
\hline \multirow{3}{*}{ Listening } & \multicolumn{2}{|c|}{$\begin{array}{l}\text { Contexts of use (questions to check the comprehension } \\
\text { of the situation presented in the excerpt) }\end{array}$} & $\begin{array}{l}\text { What does the lady want? Why? } \\
\text { Will she get what she wants? } \\
\text { How is that communicated to } \\
\text { her? }\end{array}$ \\
\hline & Communicative skills & \multicolumn{2}{|c|}{$\begin{array}{l}\text { Identification of communicative functions (make and } \\
\text { respond to complaints) } \\
\text { Identification of features of spoken language used to } \\
\text { express assertiveness }\end{array}$} \\
\hline & Linguistic aspects & \multicolumn{2}{|c|}{$\begin{array}{l}\text { I'm sorry to have to say this but... } \\
\text { I'm sorry to bother you, but... } \\
\text { Maybe you forgot to... } \\
\text { I think you might have forgotten to... } \\
\text { There may have been a misunderstanding about... } \\
\text { Don't get me wrong, but I think we should... } \\
\text { I'm sorry, but ... doesn't seem to be working }\end{array}$} \\
\hline Post-Listening & $\begin{array}{l}\text { Critical reflection (questions } \\
\text { that lead to the questioning of } \\
\text { the situation presented in the } \\
\text { oral text) }\end{array}$ & \multicolumn{2}{|c|}{$\begin{array}{l}\text { What is needed to be a hotel guest? } \\
\text { Do the people in the video look like people you know? } \\
\text { Why? Why not? } \\
\text { Have you ever stayed in a hotel? } \\
\text { What kind of people stay in hotels? }\end{array}$} \\
\hline
\end{tabular}

Integrating oral and written skills, the activity can be continued with the production of a letter to the hotel management, complaining about the hotel facilities. With this follow-up activity, there is a new opportunity for the development of critical consciousness through metatalk as additional reflective input. The pedagogical procedure suggested can focus on a common situation: problems in the provision of services and the practice of the right to complain or to formally contest the inefficiency of such services. The letter of complaint and the discussion it fosters can offer an alternative perspective to the student who might not believe in the efficacy of their complaints or who, for historical reasons, are used to being silenced (MATTOS, 2012; 2015; MONTE-MÓR, 2013). Complaining is a non- 
conformist practice and as such it is able to elicit the production of counterdiscourses, repositioning the student as an empowered member in society.

TABLE 3 - Stages of a foreign language class reconciling CA and CL: writing activity

\begin{tabular}{|c|c|c|}
\hline \multicolumn{3}{|c|}{ LETTER OF COMPLAINT } \\
\hline \multirow{5}{*}{ Pre-writing } & $\begin{array}{l}\text { Contexts of use (questions to be } \\
\text { written to check the understanding } \\
\text { of the conditions of production of } \\
\text { the text) }\end{array}$ & $\begin{array}{l}\text { Who are the people involved in the complaint? } \\
\text { What motivated the letter? } \\
\text { What is the purpose of the writer? }\end{array}$ \\
\hline & $\begin{array}{l}\text { Critical reflection (questions } \\
\text { that lead to the questioning of the } \\
\text { situation presented in the text to be } \\
\text { written) }\end{array}$ & $\begin{array}{l}\text { Who usually complains formally about the quality / } \\
\text { efficiency of services provided by third parties? } \\
\text { Who keeps silent? Why is that? }\end{array}$ \\
\hline & Discursive Aspects & Layout and textual structure of formal letters \\
\hline & Linguistic Aspects & Vocabulary repertoire of letters of complaint \\
\hline & Sociolinguistic Aspects & Politeness and assertiveness in letters of complaint \\
\hline \multirow{3}{*}{ Writing } & \multicolumn{2}{|c|}{$\begin{array}{l}\text { In pairs, students prepare an outline of the letter, reporting the events with respect to } \\
\text { the services provided by the hotel and demanding a solution / giving opinions / making } \\
\text { suggestions for the future. }\end{array}$} \\
\hline & \multicolumn{2}{|c|}{ The outline is further developed in subsequent lessons. } \\
\hline & \multicolumn{2}{|c|}{ The letter is peer-edited and rewritten for publication and socialization in the classroom } \\
\hline Post-writing & \multicolumn{2}{|c|}{$\begin{array}{l}\text { As a post-writing activity, the pairs can exchange letters with each other and respond to the } \\
\text { first letter with an apology / offer of compensation from the hotel management }\end{array}$} \\
\hline
\end{tabular}

\section{Final Thoughts}

To reconcile CL to current approaches to the teaching of a foreign language, we have tried to discuss some possible moves, indicating possible contact points between Communicative Language Teaching and Critical Literacy. We have also identified some gaps between the two approaches. However, such gaps do not seem to make them incompatible in any way.

As we have seen, the notion of literacy (BRASIL, 2006) emerges from a vision of the school curriculum as a means for citizenship education, which means enabling students to critically reflect on their position in 
society - a preference for citizenship education over curriculum content. As suggested by Freire (1970), learning the word of the oppressor should help individuals escape from marginal situations, enabling them to take a stand and implement actions that will transform their position of inferiority. The reflection afforded by critical language awareness enables the empowerment of the individual, preparing them for the recognition of their role in society and for transformative actions aimed at social justice.

However, we should attend to the fact that the objectives of CA do not exclude the needs of CL. Quite to the contrary, they may even be seen as complementary, as social criticism presupposes some control of the code, and the negotiation of meaning is a social practice that, as such, is potentially transformative.

The legitimate concern with the development of communicative competence of learners does not prevent the implementation of a curriculum that aims to integrate the demands of the objectives of CA with CL, since the two approaches seem perfectly compatible and reconcilable by means of the teacher's conscious planning and pedagogical action. Table 4 highlights the points of contact between the two approaches and indicates the gaps that need to be bridged by deliberately designed critical teaching.

TABLE 4 - Points of contact and distance between the views of Communicative Teaching and Learning and Critical Literacy

\begin{tabular}{|c|c|}
\hline \multicolumn{2}{|c|}{ Vision of Learning } \\
\hline Communicative Approach & Critical Literacy \\
\hline \multicolumn{2}{|c|}{ Learner Role } \\
\hline \multicolumn{2}{|c|}{ Heterogeneity (acknowledgement of differences) } \\
\hline \multicolumn{2}{|c|}{ Authenticity } \\
\hline \multicolumn{3}{|c|}{ Textual Genre } \\
\hline $\begin{array}{c}\text { Linguistic Awareness } \\
\text { Metalk and reflection focused on } \\
\text { problem-solving }\end{array}$ & $\begin{array}{c}\text { Critical Linguistic Awareness } \\
\text { Metatalk and reflection focused on } \\
\text { problem-posing }\end{array}$ \\
\hline
\end{tabular}

We see, therefore, that the notion of critical literacy introduced by the National Guidelines for High School Teaching (BRASIL, 2006) implies a deep reform of teaching practice in high schools, as well as of 
the materials used for this segment. In practical terms, we may say that the National Guidelines lead to the selection of texts that allow the perception of heterogeneity and the development of contextualized, meaningful activities which integrate diverse skills and focus on critical reflection. This way, language teaching becomes a means through which to achieve both goals: learners' communicative competence development and citizenship education. Consciously and deliberately exercised pedagogical action, thus, emerges as the necessary link to achieve these goals, as represented in table 5 below.

TABLE 5 - Representation of pedagogical action element as a conciliator between the objectives of CL and CA

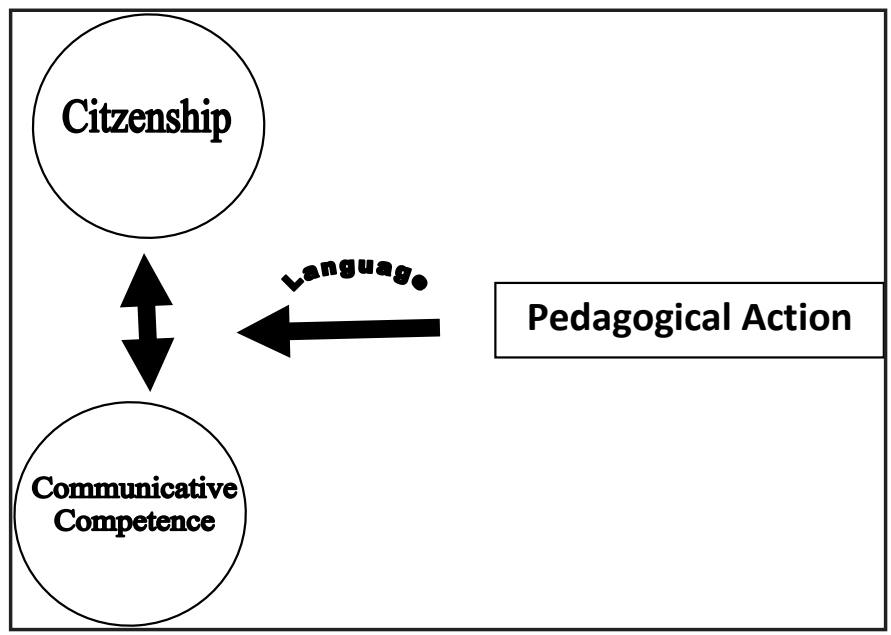

\section{References}

ALFORD, J. Learning language and critical literacy: adolescent ESL students. Journal of Adolescent \& Adult Literacy, Wiley Online Library, v. 45, n. 3, p. 238-242, 2001.

ALMEIDA FILHO, J. C. P. O ensino de línguas no Brasil de 1978. E agora? Revista Brasileira de Linguistica Aplicada, Belo Horizonte, v. 1, n. 1, p. 15-29, 2001. Available at: <http://www.scielo.br/pdf/rbla/v1n1/02.pdf>. Access on: 04 Jun. 2017.

ANDREOTTI, V. O. A postcolonial reading of contemporary discourses related to the global dimension in education in England. 2006. 229 f. Dissertation. (Ph.D.) - University of Nottingham, England, 2006. 
AUSTIN, J. L. How to do things with words. Oxford: Oxford University Press, [1962] 1975. Do: https://doi.org/10.1093/acprof:oso/9780198245537.001.0001

BAX, S. The role of genre in language syllabus design: the case of Bahrain. International Journal of Educational Development, Elsevier, v. 26, n. 3, p. 315-328, 2006. Doi: https://doi.org/10.1016/j.ijedudev.2005.09.002

BHATIA, V. K. Analysing Genre. London: Longman, 1993.

BIBLER, V. S. M. M. Bakbtin, or the Poetics of Culture. Moscow: Politizdat Press, 1991. Apud SAVIGNON, S. J. Beyond communicative language teaching: what's ahead? Journal of Pragmatics, Elsevier, v. 39, n. 1, p. 207-220, 2007.

BOXER, D. Applying sociolinguistics: domains and face-to-face interaction. Amsterdam: John Benjamins, 2002. Doi: https://doi.org/10.1075/impact.15

BOURDIEU, P. Language and symbolic power. Translation by G. Raymond; M. Adamson. Edition and Introduction by J. B. Thompson. Cambridge: Harvard University Press, 1991.

BRASIL. Parâmetros curriculares nacionais: terceiro e quarto ciclos do ensino fundamental ( $5^{a}$ a $8^{a}$ Séries) - língua estrangeira. Brasília: Ministério da Educação / Secretaria de Educação Básica, 1998. Available at: <http://portal.mec.gov.br/ seb/arquivos/pdf/pcn_estrangeira.pdf> . Access on: Oct. 252017.

BRASIL. Orientações curriculares para o ensino médio: linguagens, códigos e suas tecnologias - conhecimentos de línguas estrangeiras. Brasília: Ministério da Educação / Secretaria de Educação Básica, 2006. Available at: <http://portal. mec.gov.br/seb/arquivos/pdf/book_volume_01_internet.pdf $>$. Access on: Feb. 6, 2008.

CANAGARAJAH, A. S. Translingual practice: global Englishes and cosmopolitan relations. New York: Routledge, 2013.

CANALE, M.; SWAIN, M. Theoretical bases of communicative approaches to second language teaching and testing. Applied Linguistics, Oxford, v. 1, n. 1, p. 1-47, 1980. Doi: https://doi.org/10.1093/applin/1.1.1

CELCE-MURCIA, M.; OLSHTAIN, E. Discourse and language teaching: a guide for language teachers. Cambridge: Cambridge University Press, 2000.

CERVETTI, G.; PARDALES, M. J.; DAMICO, J. S. A tale of differences: comparing the traditions, perspectives and educational goals of critical reading and critical literacy. Reading Online, v. 4, n. 9, 2001. Available at: <http://www. readingonline.org/articles/art_index.asp?HREF=/articles/cervetti/index.html $>$. Access on: Mar. 30, 2007. 
COPE, B; KALANTZIS, M. Multiliteracies: literacy learning and the design of social futures. London: Routledge, 2000.

COX, M. I. P.; ASSIS-PETERSON, A. A. O drama do ensino de inglês na escola pública brasileira. In: ASSIS-PETERSON, A. A. (Org.). Linguas estrangeiras: para além do método. São Carlos: Pedro \& João Editores; Cuiabá: EdUFMT, 2008. p. 19-54.

CRAWFORD, J. The role of materials in the language classroom: finding the balance. In: RICHARDS, J. J.; RENANDYA, W. A. (Ed.). Methodology in language teaching. Cambridge: Cambridge University Press, 2002. p. 80-90. Doi: https://doi. org/10.1017/CBO9780511667190.013

CRAWSHAW, R. Intercultural awareness as a component of HE Modern Language courses in the UK, 2005. Available at: <http://www.llas.ac.uk/resources/ goodpractice. aspx? resourceid=2303>. Access on: Oct. 18, 2006.

HYMES, D. Models of the interaction of language and social life. In: GUMPERZ, J. J.; HYMES, D. (Ed.). Directions in sociolinguistics: the ethnography of communication. New York: Holt, Rinehart \& Winston, 1972. p. 3571.

ELLIS, R. Instructed second language acquisition: A literature review. Wellington: The Research Division of the New Zealand Ministry of Education, 2005. Available at: <www.minedu.govt.nz >. Access on: Aug. 20, 2007.

FREIRE, P. Pedagogia do oprimido. Rio de Janeiro: Paz e Terra, 1970.

FREIRE, P. Pedagogy of the oppressed. Trad. Myra Bergman Ramos. New York: Continuum, [1970] 2005.

GARCIA, O. Misconstructions in the education of language minoritized students. In: ROCHA, C. H.; MACIEL, R. F. (Org.). Lingua estrangeira e formação cidadã: por entre discursos e práticas. 2. ed. Campinas: Pontes, 2015. p. 217-230.

HALLIDAY, M. A. K. Language as social semiotic the social interpretation of language and meaning. London: Edward Arnold, 1978.

HAMMOND, J.; DEREWIANKA, B. Genre. In: CARTER, R.; NUNAN, D. (Ed.). The Cambridge guide to teaching English to speakers of other languages. Cambridge: Cambridge University Press, 2001. p. 186-193. Doi: https://doi.org/10.1017/ CBO9780511667206.028

HAWKINS, E. W. Foreign language study and language awareness. Language Awareness, Taylor \& Francis Online, v. 8, n. 3-4, p. 124-142, 1999.

JACOBS, J. M.; SHEGAR, C. Reading as social practice. In: LIONTAS, J. I. (Ed.). The TESOL encyclopedia of English language teaching. Singapore: TESOL International Association; Wiley Blackwell, 2018. v. 4, p. 2196-2201. 
JAMES, C.; GARRETT, P. (Ed.). Language awareness in the classroom. London: Longman, 1991.

JENKINS, J. Current perspectives on teaching World Englishes and English as a Lingua Franca. TESOL Quarterly, Wiley Online Library, v. 40, n. 1, p. 157-181, 2006.

JOHNS, A. M. et al. Crossing the boundaries of genre studies: commentaries by experts. Journal of Second Language Writing, Elsevier, v. 15, p. 234-249, 2006. Doi: https://doi.org/10.1016/j.jslw.2006.09.001

JORDÃO, C. M. Uma breve história da leitura no século xx, ou de como se podem calar as nativas. Revista de Letras, Curitiba, v. 5, 2002. Available at: <http://www. dacex.ct.utfpr.edu.br/clarisse5.htm>. Access on: Aug. 20, 2007. Doi: https://doi. org/10.3895/rl.v0n5.2314

JORDÃO, C. M. ILA - ILF - ILE - ILG: quem dá conta? Revista Brasileira de Linguistica Aplicada, Belo Horizonte, v. 14, n. 1, p. 13-40, 2014. Doi: https://doi. org/10.1590/S1984-63982014000100002

JUNG, J. Issues in acquisitional pragmatics. Working papers in TESOL \& Applied Linguistics. New York, v. 2, n. 2, p. 1-34, 2001. Available at: <http://www. tc.columbia.edu/academic/tesol/webjournal>. Access on: Aug. 20, 2002.

LANKSHEAR, C.; KNOBEL, M. New literacies: changing knowledge and classroom learning. Buckingham: Open University Press, 2003.

MATTOS, A. M. A. Education for citizenship: introducing critical literacy in the EFL classroom. In: GILLIES, R. M. (Ed.). Pedagogy: new developments in the learning sciences. New York: Nova Publishers, 2012. p. 191-212.

MATTOS, A. M. A. Ensino de inglês como lingua estrangeira na escola pública: letramentos, globalização e cidadania. Jundiaí: Paco, 2015.

McDONOUGH, J.; SHAW, C. Materials and methods in ELT: a teacher's guide. Oxford: Blackwell, 2003.

McLAUGHLIN, M.; DeVOOGD, G. L. Critical literacy: enhancing students' comprehension of text. New York: Scholastic, 2004.

MONTE-MÓR, W. M. The development of agency in a new literacies proposal for teacher education in Brazil. In: JUNQUEIRA, E. S.; BUZATO, M. K. (Ed.). New literacies, new agencies? A Brazilian perspective on mindsets, digital practices and tools for social action in and out of school. Pieterlen, Switzerland: Peter Lang, 2013. p. 126-146. 
MONTE-MÓR, W. M.; MORGAN, B. Between conformity and critique: developing 'activism' and active citizenship: dangerous pedagogies? Interfaces BrasilCanada, Pelotas, v. 14, n. 2, p. 16-35, 2014. Available at: <http://www.revistas. unilasalle.edu.br/index.php/interfaces/article/view/1838>. Access on: Aug. 12, 2015.

MORIN, E. A cabeça bem-feita: repensar a reforma - reformar o pensamento. Rio de Janeiro: Bertrand Brasil, 2000.

NAYLOR, S.; KEOGH, B. Constructivism in classroom: theory into practice. Journal of Science Teacher Education, Springer Link, v. 10, n. 2, p. 93-106, 1999. Available at: <https://link.springer.com/article/10.1023/A\%3A1009419914289>. Access on: Oct. 25, 2017.

NORTON, B. Critical literacy and international development. Critical Literacy: Theories and Practices, [s.l.], v. 1, n. 1, p. 6-15, 2007. Available at: <http://www. criticalliteracy.org.uk/images/journal/v1issue1/norton.pdf $>$. Access on: May 22, 2008.

NUNAN, D. Second language teaching and learning. Boston, MA: Heinle \& Heinle, 1999.

PALTRIDGE, B. Genre and the language learning classroom. Ann Arbor: The University of Michigan Press, 2001. Doi: https://doi.org/10.3998/mpub.23749

RICHARDS, J. C. Communicative language teaching today. New York: Cambridge University Press, 2006.

RICHARDS, J. C.; RODGERS, T. S. Approaches and methods in language teaching. New York: Cambridge University Press, 2001. Doi: https://doi.org/10.1017/ CBO9780511667305

SAVIGNON, S. J. Communicative language teaching for the twenty-first century. In: CELCE-MURCIA, M. (Ed.). Teaching English as a second or foreign language. Boston, MA: Heinle \& Heinle, 2001. p. 13-28.

SAVIGNON, S. J. Beyond communicative language teaching: what's ahead? Journal of Pragmatics, Elsevier, v. 39, n. 1, p. 207-220, 2007. Doi: https://doi.org/10.1016/j. pragma.2006.09.004

SEARLE, J. R. Speech act: an essay in the philosophy of language. Cambridge: Cambridge University Press, 1969. Doi: https://doi.org/10.1017/ CBO9781139173438

SEARLE, J. R. What is a speech act? In: SEARLE, J. R. (Ed.). The philosophy of language. London: Oxford University Press, 1971. p. 3953. 
SILVER, D. Multimedia, multilinearity, and multivocality in the hypermedia classroom. Computers \& Texts, v. 14, 1997. Available at: < http://users.ox.ac. uk/ c ctitext2/publish/comtxt/ct14/silver.html> Access on: Jun. 04, 2008.

SOKOLIK, M. Computers in language teaching. In: CELCE-MURCIA, M. (Ed.). Teacbing English as a second or foreign language. Boston, MA: Heinle \& Heinle, 2001. p. 477-488.

SVALBERG, A. M. L. Language awareness and language learning. Language Teaching, Cambridge, v. 40, n. 4, p. 287-308, 2007. Doi: https://doi.org/10.1017/ S0261444807004491

SWALES, J. Genre analysis: English in academic and research settings. Cambridge: Cambridge University Press, 1990.

TOCALLI-BELLER, A.; SWAIN, M. Reformulation: The cognitive conflict and L2 learning it generates. International Journal of Applied Linguistics, Wiley Online Library, v. 15, n. 1, p. 5-28, 2005.

WIDDOWSON, H. The roles of teacher and learner. ELT Journal, Oxford, v. 41, n. 2, p. 83-88, 1987. Doi: https://doi.org/10.1093/elt/41.2.83

Data de submissão: 17/06/2017. Data de aprovação: 12/09/2017. 